University of Nebraska - Lincoln

DigitalCommons@University of Nebraska - Lincoln

Biological Systems Engineering: Papers and

Publications

Biological Systems Engineering

$5-2002$

\title{
Sodium dodecyl sulfate treatment improves properties of cast films from soy protein isolate
}

Jong W. Rhim

Mokpo National University, Korea

Aristippos Gennadios

Banner Pharmacaps Inc., aris.gennadios@catalent.com

Curtis Weller

University of Nebraska-Lincoln, cweller1@unl.edu

Milford Hanna

University of Nebraska-Lincoln, mhanna1@unl.edu

Follow this and additional works at: https://digitalcommons.unl.edu/biosysengfacpub

Part of the Biological Engineering Commons

Rhim, Jong W.; Gennadios, Aristippos; Weller, Curtis; and Hanna, Milford, "Sodium dodecyl sulfate treatment improves properties of cast films from soy protein isolate" (2002). Biological Systems Engineering: Papers and Publications. 198.

https://digitalcommons.unl.edu/biosysengfacpub/198

This Article is brought to you for free and open access by the Biological Systems Engineering at DigitalCommons@University of Nebraska - Lincoln. It has been accepted for inclusion in Biological Systems Engineering: Papers and Publications by an authorized administrator of DigitalCommons@University of Nebraska Lincoln. 


\title{
Sodium dodecyl sulfate treatment improves properties of cast films from soy protein isolate
}

\author{
Jong W. Rhim, ${ }^{1}$ Aristippos Gennadios, ${ }^{2}$ \\ Curtis L. Weller, ${ }^{3}$ and Milford A. Hanna ${ }^{3}$
}

1. Department of Food Engineering, Mokpo National University, 61 Dorim-ri, Chungkye-myon, Muan-gun, Chonnam 534-729, Republic of Korea

2. Product Development, Materials Science Group, Research and Development, Banner Pharmacaps Inc., 4125 Premier Drive, High Point, NC 27265-8144, USA

3. Industrial Agricultural Products Center and Department of Biological Systems Engineering, University of Nebraska-Lincoln, Lincoln, NE 68583-0730, USA

Corresponding author - A. Gennadios, tel 336 812-8700, fax 336 812-9091, email agennadios@banpharm.com

\begin{abstract}
The manufacture of edible/biodegradable films or coatings can potentially add value to soy protein. This study was conducted to determine the effect of sodium dodecyl sulfate (SDS) on selected physical properties of glycerin-plasticized soy protein isolate (SPI) films. Films were cast from heated $\left(70{ }^{\circ} \mathrm{C}\right.$ for $\left.20 \mathrm{~min}\right)$, alkaline ( $\left.\mathrm{pH} 10\right)$ aqueous solutions of SPI ( $5 \mathrm{~g} / 100 \mathrm{ml}$ water), glycerin (50\% w/w of SPI), and SDS $(0,5,10,20,30$, or $40 \% \mathrm{w} / \mathrm{w}$ of SPI). Tensile strength (TS), elongation at break (E), moisture content (MC), total soluble matter (TSM), water vapor permeability (WVP), and color values $(L, a$, and $b$ ) were determined after conditioning film specimens at $25{ }^{\circ} \mathrm{C}$ and $50 \%$ relative humidity $(\mathrm{RH})$ for 2 days. SDS reduced $(P<0.05)$ film TS by as much as $43 \%$ for films with $40 \%$ SDS (6.2 vs. $10.9 \mathrm{MPa}$ for control SPI films). In contrast, film E increased $(P<0.05)$ notably with addition of SDS even at $5 \%$. Films with SDS had smaller $(P<0.05)$ MC and larger $(P<0.05)$ TSM values than control SPI films. Films containing $10 \%$ or more SDS had lower WVP values than control SPI films by as much as $50 \%$. Increased yellowness, evidenced by greater $(P<0.05)+b$ color values, was noted for films with high amounts $(20,30$, or $40 \%)$ of SDS. Changes in tensile, solubility, and water vapor barrier properties of SPI films due to the addition of SDS were largely attributed to disruption of hydrophobic associations among neighboring protein molecules as the non-polar portions of the SDS molecules attached onto hydrophobic amino acid residues within the film structure. It was demonstrated that adding anionic surfactant SDS to film-forming solutions prior to casting could greatly modify the properties of SPI films. In particular, SDS improved the water vapor barrier ability and the extendibility of SPI films, both desirable attributes when assessing the potential of such films for packaging applications.
\end{abstract}

Keywords: protein films, soy protein, sodium dodecyl sulfate, water vapor permeability 


\section{Introduction}

The manufacture of edible/biodegradable films or coatings can potentially add value to soy protein. Soy protein-based films formed on the surface of heated soymilk have traditionally been prepared in the Far East (Gennadios et al., 1994a). Also, free-standing soy protein films can be formed by casting (Brandenburg et al., 1993; Gennadios et al., 1993), extrusion (Naga et al., 1996), spinning in a coagulating buffer (Rampon et al., 1999), or thermal compaction (Cunningham et al., 1999; Ogale et al., 2000). Plasticizers, typically glycerin and/or sorbitol are added to soy protein films to impart flexibility (Gennadios et al., 1994a).

Various physical (Gennadios et al., 1996, 1998a; Rangavajhyala et al., 1997; Rhim et al., 1999a, 2000), chemical (Ghorpade et al., 1995; Rhim et al., 1998, 1999b, 2000; Were et al., 1999), or enzymatic (Motoki et al., 1987; Stuchell and Krochta, 1994; Yildirim and Hettiarachchy, 1997) treatments have been used to modify the properties of soy protein films. Such treatments mainly promote cross-linking within the protein film network. Ionic surfactants, such as sodium dodecyl sulfate (SDS), are powerful denaturing and dissociating agents for proteins (Graveland et al., 1979; Cheftel et al., 1985). Strength reduction, and even re-solubilization, of protein gels in SDS buffers has been reported (Kitabatake and Doi, 1993; McClements et al., 1993; Kiosseoglou et al., 1999). Therefore, incorporation of SDS into protein-based film-forming solutions would be expected to affect the structure and properties of cast protein films. Fairley et al. (1996) reported that SDS showed potential for use as an adjunct to polyols (i.e. glycerol and sorbitol) for the plasticization of whey protein isolate films. Our objective was to investigate the effects of SDS on selected physical properties (i.e. tensile strength, elongation at break, total soluble matter, water vapor permeability, and color) of cast soy protein isolate (SPI) films.

\section{Materials and methods}

\subsection{Film preparation}

Film-forming solutions were prepared by slowly dissolving $5 \mathrm{~g}$ of SPI (minimum $90 \%$ protein content on dry basis, SUPRO 620, Protein Technologies International, St. Louis, MO) in a constantly stirred mixture of distilled water $(100 \mathrm{ml})$ and glycerin $(2.5 \mathrm{~g})$. Glycerin was added as a plasticizer to overcome film brittleness and to obtain freestanding films. The solution $\mathrm{pH}$ was adjusted to $10 \pm 0.1$ with $1 \mathrm{M}$ sodium hydroxide. Alkaline conditions favor SPI film formation, presumably by aiding protein dispersion in film-forming solutions (Okamoto, 1978; Gennadios et al., 1993). After heating the solutions for $20 \mathrm{~min}$ at $70{ }^{\circ} \mathrm{C}$ in a constant temperature water bath, they were strained through eight-layered cheese cloth (grade 40, Fisher Scientific, Pittsburgh, PA) to remove any small lumps (minuscule amounts), and cast onto leveled, Teflon ${ }^{\circledR}$-coated glass plates $(21 \times 35 \mathrm{~cm})$. Film thickness was controlled by casting the same amount $(80 \mathrm{ml})$ of film-forming solution per plate. The castings were dried at ambient conditions $\left(25^{\circ} \mathrm{C}\right)$ for about 20 h. Dried films were peeled from the plates and specimens, for property testing, were cut $(2.54 \times 10 \mathrm{~cm}$ for tensile testing; $2 \times 2 \mathrm{~cm}$ for moisture content and total soluble matter; and $7 \times 7 \mathrm{~cm}$ for water vapor permeability and color measurements). In addition to 'control' films prepared in this manner, films also were prepared by adding SDS (Fisher Scientific) at 5, 10, 20, 30, or $40 \%$ $\mathrm{w} / \mathrm{w}$ of SPI into the film-forming solutions prior to $\mathrm{pH}$ adjustment.

\subsection{Film thickness and conditioning}

Film thickness was measured to the nearest $2.54 \mu \mathrm{m}$ with a hand-held micrometer (B.C. Ames Co, Waltham, MA). Five thickness measurements were taken on each tensile testing specimen along the length of the rectangular strip and the mean value was used in tensile strength calculations. Similarly, five measurements were taken on 
each water vapor permeability specimen, one at the center and four around the perimeter, and the mean values were used in calculating water vapor permeability. All film specimens were conditioned for 2 days in an environmental chamber (Model RC5492, Parameter Generation \& Control, Inc, Black Mountain, NC) at $50 \%$ relative humidity (RH) and $25^{\circ} \mathrm{C}$ before testing.

\subsection{Tensile testing}

Film tensile strength (TS) and percentage elongation at break $(E)$ were determined with an Instron Universal Testing Machine (model 5566, Instron Engineering Corp, Canton, MA). Initial grip separation was set at $50 \mathrm{~mm}$ and cross-head speed was set at $500 \mathrm{~mm} / \mathrm{min}$. TS was calculated by dividing the maximum load by the initial crosssectional area of the specimen (ASTM, 1995a). E was calculated by dividing the extension at rupture of the specimen by the initial gage length of the specimen $(50 \mathrm{~mm})$ and multiplying by 100 (ASTM, 1995a). TS and $E$ measurements for each type of film were replicated three times with individually prepared films as the replicated experimental units and each replicate being the mean of two tested sampling units (specimens) taken from the same film.

\subsection{Moisture content}

Film samples were weighed $( \pm 0.0001 \mathrm{~g})$ into aluminum dishes and dried in an air-circulating oven at $105^{\circ} \mathrm{C}$ for $24 \mathrm{~h}$. Moisture content (MC) was determined as the percentage of initial film weight lost during drying and reported on a wet basis. Triplicate measurements of MC were obtained for each type of film with individually prepared films as replicated experimental units and three specimens tested from each film.

\subsection{Total soluble matter}

Total soluble matter (TSM) was determined as the percentage of film dry matter solubilized after $24 \mathrm{~h}$ immersion in distilled water. Proteins are susceptible to heat-induced cross-linking (Cheftel et al., 1985). Heat treatments have increased the water resistance of soy protein films (Gennadios et al., 1996; Rangavajhyala et al., 1997; Rhim et al., 2000). Therefore, to avoid heat curing, film specimens were not dried in an oven to determine their initial dry matter prior to solubility testing (Rhim et al., 1998). Instead, the initial dry matter of conditioned films was determined on different specimens (two from each film) by drying in an air-circulating oven $\left(105^{\circ} \mathrm{C}\right.$ for $\left.24 \mathrm{~h}\right)$.

\subsection{Water vapor permeability}

Water vapor permeability (WVP) (g mm/ $\mathrm{m}^{2} \mathrm{~h} \mathrm{kPa}$ ) was calculated from:

$$
\mathrm{WVP}=\frac{\mathrm{WVTR} \cdot L}{\Delta p}
$$

where WVTR was the measured water vapor transmission rate $\left(\mathrm{g} / \mathrm{m}^{2} \mathrm{~h}\right)$ through the film specimen; $L$ was the mean film thickness (mm); and $\Delta p$ was the partial water vapor pressure difference $(\mathrm{kPa})$ across the two sides of the film specimen.

WVTR was determined gravimetrically using a modified ASTM Method E 96-95 (ASTM, 1995b). Film specimens were mounted horizontally on poly(methylmethacrylate) cups filled with distilled water up to $1 \mathrm{~cm}$ from the bottom side of the film. The design of the cups was described by Gennadios et al. (1994b). The cups were placed in an environmental chamber at $25{ }^{\circ} \mathrm{C}$ and $50 \%$ RH. A fan was operated within the chamber (air velocity of $198 \mathrm{~m} / \mathrm{min}$ ) to remove permeating water vapors from the surface of the cups. The cups were weighed every hour for a period of $6 \mathrm{~h}$. Steady state was reached within $1 \mathrm{~h}$. The slopes of the steady state (linear) portion of weight loss versus time curves were used to calculate WVTR. Due to the low water vapor resistance of the hydrophilic SPI films, actual RH values at the film surfaces facing the water during testing were less than the theoretical value of $100 \%$. Actual $\mathrm{RH}$ values at the film surfaces facing the water and film WVP values were calculated after accounting for the resistance of the stagnant air layer between the film surfaces facing the water and the water surface in the cups (Gennadios et al., 1994b; 
McHugh et al., 1994). The mean of the initial and final stagnant air gap heights was used in the calculations. For each type of film, WVP measurements were replicated three times with individually prepared films as the replicated experimental units and each replicate being the mean of two tested sampling units (specimens) taken from the same film.

\subsection{Color measurements}

Color values of the films were measured with a portable colorimeter (CR-300 Minolta Chroma Meter, Minolta Camera Co., Osaka, Japan). Film specimens were placed on a white standard plate (calibration plate CR-A43; $L=96.86, a=-0.02$, and $b=1.99$ ) and the $L, a$, and $b$ color values were measured. $L$ values range from 0 (black) to 100 (white); $a$ values range from -80 (greenness) to 100 (redness); and $b$ values range from -80 (blueness) to 70 (yellowness). Five measurements were taken on each specimen, one at the center and four around the perimeter. Color measurements for each type of film were replicated three times with individually prepared films as the replicated experimental units.

\subsection{Statistical analysis}

Statistics on a completely randomized experimental design were determined using the General Linear Models procedure in SAS software (SAS, 1993). Significantly $(P<$ $0.05)$ different means were separated with Duncan's multiple range test.

\section{Results and discussion}

\subsection{Tensile properties}

The addition of SDS substantially reduced $(P$ $<0.05)$ the TS of SPI films by as much as $43 \%$ for films with $40 \%$ SDS (Table 1). In general, the formation of SPI film and gel structures involves covalent disulfide bonds as well as hydrophobic interactions and hydrogen bonds (Fukushima and Van Buren, 1970; Farnum et al., 1976; Doi and Kitabatake, 1989). SDS does not cleave disulfide bonds, but it prevents hydrophobic associations among protein molecules (Fukushima and Van Buren, 1970; Kitabatake and Doi, 1993). This is accomplished through attachment of the hydrophobic (non-polar) portions of the SDS molecules onto hydrophobic amino acid residues (Krull and Wall, 1969). Therefore, it is likely that the reduced TS of SDS-containing SPI films was related to formation of "weaker" structures due to lack of hydrophobic interactions among neighboring protein molecular chains. In addition to its hydrophobic portion, the SDS molecule also carries an anionic (polar) portion. Since the $\mathrm{pH}$ of the film-forming solutions was markedly greater than the approximate isoelectric point of soy protein $(\mathrm{pH} 4.5)$, protein chains were mainly negative charged. The attached SDS molecules further increased the negative charges along protein molecular chains. This highly charged state of the protein molecules could have further contributed to low film TS values as strong repulsive forces could have decreased the occurrence of molecular associations within the protein matrix.

Table 1. Tensile strength (TS), elongation at break (E), moisture content (MC), and total soluble matter (TSM) of cast films from soy protein isolate (SPI) treated with different levels of sodium dodecyl sulfate (SDS)

\begin{tabular}{ccccc}
\hline SDS $(\% \mathrm{w} / \mathrm{w}$ of SPI $)$ & TS $(\mathrm{MPa})^{\mathrm{a}}$ & $\mathrm{E}(\%)^{\mathrm{a}}$ & $\mathrm{MC}(\% \mathrm{wb})^{\mathrm{a}}$ & TSM $(\%)^{\mathrm{a}}$ \\
\hline 0 & $10.9 \pm 0.8 a$ & $50 \pm 6 c$ & $23.0 \pm 1.2 a$ & $25.3 \pm 0.4 c$ \\
5 & $8.4 \pm 0.6 b$ & $156 \pm 11 b$ & $22.3 \pm 0.4 b$ & $25.3 \pm 4.2 c$ \\
10 & $7.3 \pm 0.3 b c$ & $192 \pm 15 a$ & $22.0 \pm 0.8 b$ & $32.1 \pm 2.0 b$ \\
20 & $7.1 \pm 0.6 b c$ & $209 \pm 25 a$ & $21.2 \pm 0.2 c$ & $36.0 \pm 3.0 a b$ \\
30 & $6.4 \pm 0.7 c$ & $190 \pm 15 a$ & $21.4 \pm 0.5 c$ & $35.8 \pm 3.4 a b$ \\
40 & $6.2 \pm 0.2 c$ & $186 \pm 12 a b$ & $17.2 \pm 0.3 d$ & $37.0 \pm 0.7 a$
\end{tabular}

a. Means of three replicates \pm standard deviations. Means in the same column followed by the same letter are not significantly $(P>0.05)$ different by Duncan's multiple range test. 
In contrast to TS, film E values increased $(P<0.05)$ notably with the addition of SDS (Table 1). For example, films with 5\% SDS had three times greater $E$ than control films. This can be attributed to SDS-induced unfolding of the protein chains. In general, by disrupting hydrophobic interactions in proteins, SDS separates polypeptide chains into 'rod-shaped' units (Graveland et al., 1979). Therefore, the greater $E$ could have resulted from a more linear orientation of protein molecules in SPI films containing SDS. Similarly, Fairley et al. (1996) reported that SDS had a moderate plasticization effect on whey protein isolate films when used in combination with glycerol, as in our SPI films, or sorbitol, although SDS could not plasticize films on its own.

\subsection{Moisture content and total soluble matter}

The MC of the SPI films, after conditioning at $25{ }^{\circ} \mathrm{C}$ and $50 \%$ RH for 2 days, decreased $(P<0.05)$ with the addition of SDS (Table $1)$. This was likely partially due to the hydrophobic portions of the SDS molecules. Also, the amount of glycerol per gram of film decreased as the amount of added SDS increased. Since glycerol is highly hydrophilic and a strong humectant, the smaller glycerol content per gram of film resulted in smaller amounts of bound water, and smaller MC values. Therefore, the presence of SDS can possibly reduce the susceptibility of protein films to $\mathrm{RH}$ changes.

TSM can be viewed as a measure of the water resistance and the integrity of a film. Films with $10 \%$ or more SDS had notably greater $(P<0.05)$ TSM values than control SPI films (Table 1). For example, films with $40 \%$ SDS had greater TSM than control films by about $46 \%$. The larger solubility of the SDS-containing films was probably linked to the "weaker" structure of such films as evidenced by their smaller TS values compared with control SPI films.

\subsection{Water vapor permeability}

Films containing $10 \%$ or more SDS had smaller $(P<0.05)$ WVP values than control SPI films (Table 2). The mean WVP value of films with $40 \%$ SDS was almost one-half that of the control films. Similar to MC values, this was likely due to the hydrophobic portions of the SDS molecules, which decreased the rate of sorption and diffusion of water molecules through the film structures. Poor water vapor barrier ability is generally considered a major limitation to the use of protein films as packagings (Gennadios et al., 1994a; Krochta and De Mulder-Johnston, 1997). Therefore, the reduction in film WVP accompanying SDS addition is desirable for the functionality of SPI films. Gennadios et al. (1998b) reported that incorporation of saturated fatty acids such as lauric acid, myristic acid, and palmitic acid also re-

Table 2. Water vapor permeability (WVP) of cast films from soy protein isolate (SPI) treated with different levels of sodium dodecyl sulfate (SDS)

\begin{tabular}{cccc}
\hline SDS $(\% \mathrm{w} / \mathrm{w}$ of SPI $)$ & Thickness $(\mu \mathrm{m})$ & $\mathrm{WVP}\left(\mathrm{g} \mathrm{mm} / \mathrm{m}^{2} \mathrm{~h} \mathrm{kPa}\right)^{\mathrm{a}}$ & RH inside cup $(\%)^{\mathrm{a}, \mathrm{b}}$ \\
\hline 0 & $72 \pm 2$ & $10.1 \pm 0.5 a$ & $66.2 \pm 0.5 \mathrm{f}$ \\
5 & $84 \pm 3$ & $10.2 \pm 0.8 a$ & $67.9 \pm 0.7 \mathrm{e}$ \\
10 & $84 \pm 1$ & $8.6 \pm 0.3 b c$ & $69.9 \pm 0.3 d$ \\
20 & $86 \pm 8$ & $7.8 \pm 0.9 a$ & $71.4 \pm 0.3 \mathrm{c}$ \\
30 & $79 \pm 2$ & $6.4 \pm 0.1 d$ & $72.8 \pm 0.2 b$ \\
40 & $83 \pm 8$ & $5.6 \pm 0.4 d$ & $75.2 \pm 0.5 a$ \\
\hline
\end{tabular}

a. Means of three replicates \pm standard deviations. Means in the same column followed by the same letter are not significantly $(P>0.05)$ different by Duncan's multiple range test.

b. Actual RH values at film surfaces facing the water calculated as described by Gennadios et al. (1994b) to account for resistance of stagnant air layer between film and water surface in testing cups. RH outside cups was $50 \%$. 
duced the WVP of glycerin-plasticized SPI films. However, such films had poor structural integrity as evidenced by their lower TS and $E$ values compared with control SPI films. In contrast, SDS successfully reduced WVP while also increasing film extendibility. Nevertheless, the WVP values of SDScontaining SPI films were still two to four orders of magnitude greater than the WVP values reported for polyethylene, polypropylene, and polyester type polymeric films (Briston, 1988).

\subsection{Color}

The effects of SDS addition on $L$ and $a$ color values of SPI films were practically inconsequential (Table 3). However, films with large amounts $(20,30$, or $40 \%)$ of SDS had greater $(P<0.05)+b$ color values (increased yellowness) (Table 3). Increased yellowness (greater $b$ color values) of SPI films as a result of heat curing (Gennadios et al., 1996), UV radiation (Gennadios et al., 1998a), or cross-linking with dialdehyde starch (Rhim et al., 1998) has been reported. In general, edible/biodegradable films should be as close to colorless as possible to simulate the appearance of common polymeric films. However, the increased yellowness of SPI films with large amounts of SDS, which was attributed to the inherent color of SDS, was not considered visually detrimental.

Table 3. $L, a$, and $b$ color values of cast films from soy protein isolate (SPI) treated with different levels of sodium dodecyl sulfate (SDS)

\begin{tabular}{|c|c|c|c|}
\hline $\begin{array}{l}\text { SDS (\% } \\
w / w \\
\text { of SPI) }\end{array}$ & $L^{\mathrm{a}}$ & $a^{\mathrm{a}}$ & $b^{\mathrm{a}}$ \\
\hline 0 & $90.04 \pm 0.28 a$ & $-3.32 \pm 0.15 d$ & $15.95 \pm 0.83 c$ \\
\hline 5 & $92.48 \pm 0.18 b$ & $-3.02 \pm 0.05 b c$ & $16.25 \pm 0.41 c$ \\
\hline 10 & $92.68 \pm 0.09 a b$ & $-3.51 \pm 0.10 e$ & $17.13 \pm 0.53 c$ \\
\hline 20 & $91.06 \pm 0.27 c$ & $-2.98 \pm 0.08 a b$ & $19.31 \pm 0.87 b$ \\
\hline 30 & $90.62 \pm 0.08 d$ & $-2.84 \pm 0.01 a$ & $19.36 \pm 0.19 b$ \\
\hline 40 & $90.45 \pm 0.32 d$ & $-3.17 \pm 0.03 c d$ & $22.14 \pm 0.74 a$ \\
\hline
\end{tabular}

a. Means of three replicates \pm standard deviations. Means in the same column followed by the same letter are not significantly $(P>0.05)$ different by Duncan's multiple range test.

\section{Conclusions}

Functional properties of glycerin-plasticized SPI films can be modified by incorporation of SDS. Specifically, SDS appears to increase substantially film extendibility while simultaneously improving the moisture barrier ability of the films. These are both desirable improvements in considering such films for packaging applications. However, these improvements are realized at the expense of reduced film tensile strength.

Acknowledgments - We acknowledge support from the Food Industrial Technology Research Center (Republic of Korea) and the Nebraska Soybean Board.

\section{References}

ASTM, 1995a - ASTM, Standard test methods for tensile properties of thin plastic sheeting (D 88291). In: Annual Book of ASTM Standards 8. 01, American Society for Testing and Materials, West Conshohochen, PA (1995a), pp. 182-190.

ASTM, 1995b - ASTM, Standard test methods for water vapor transmission of materials (E 96-95). In: Annual Book of ASTM Standards 4. 06, American Society for Testing and Materials, West Conshohochen, PA (1995b), pp. 697-704.

Brandenburg et al., 1993 - A. H. Brandenburg, C. L. Weller, and R. F. Testin, Edible films and coatings from soy protein. J. Food Sci. 58 (1993), pp. 1086-1089.

Briston, 1988 - J. H. Briston In: Plastics Films (third ed.), Wiley, New York (1988), p. 434 Appendix A.

Cheftel et al., 1985 - Cheftel, J. C., Cuq, J. L., Lorient, D., 1985. Amino acids, peptides, and proteins. In: O. R. Fennema (Ed.), Food Chemistry. Marcel Dekker, New York, pp. 279, 336.

Cunningham et al., 2000 - P. Cunningham, A. A. Ogale, P. L. Dawson, and J. C. Acton, Tensile properties of soy protein isolate films produced by a thermal compaction technique. J. Food Sci. 65 (2000), pp. 668-671.

Doi and Kitabatake, 1989 • E. Doi and N. Kitabatake, Structure of glycinin and ovalbumin gels. Food Hydrocolloids 3 (1989), pp. 327-337.

Fairley et al., 1996 - P. Fairley, F. J. Monahan, J. B. German, and J. M. Krochta, Mechanical properties and water vapor permeability of edible films from whey protein isolate and sodium dodecyl sulfate. J. Agric. Food Chem. 44 (1996), pp. 438-443.

Farnum et al., 1976 - C. Farnum, D. W. Stanley, and J. I. Gray, Protein-lipid interactions in soy films. Can. Inst. Food Sci. Technol. J. 9 (1976), pp. 201-206. 
Fukushima and Van Buren, 1970 - D. Fukushima and J. Van Buren, Mechanisms of protein insolubilization during the drying of soy milk. Role of disulfide and hydrophobic bonds. Cereal Chem. 47 (1970), pp. 687-696.

Gennadios et al., 1993 - A. Gennadios, A. H. Brandenburg, C. L. Weller, and R. F. Testin, Effect of $\mathrm{pH}$ on properties of wheat gluten and soy protein isolate films. J. Agric. Food Chem. 41 (1993), pp. 1835-1839.

Gennadios et al., 1994a - A. Gennadios, T. H. McHugh, C. L. Weller, and J. M. Krochta, Edible coatings and films based on proteins. In: J. M. Krochta, E. A. Baldwin, and M. Nisperos-Carriedo, Editors, Edible Coatings and Films to Improve Food Quality, Technomic Publishing Company, Lancaster, PA (1994), pp. 201-277.

Gennadios et al., 1994b - A. Gennadios, C. L. Weller and C. H. Gooding, Measurement errors in water vapor permeability of highly permeable, hydrophilic edible films. J. Food Eng. 21 (1994), pp. 395-409.

Gennadios et al., 1996 - A. Gennadios, V. M. Ghorpade, C. L. Weller and M. A. Hanna, Heat curing of soy protein films. Trans. ASAE 39 (1996), pp. 575-579.

Gennadios et al., 1998a - A. Gennadios, J. W. Rhim, A. Handa, C. L. Weller and M. A. Hanna, Ultraviolet radiation affects physical and mechanical properties of soy protein films. J. Food Sci. 63 (1998), pp. 225-228.

Gennadios et al., 1998b - A. Gennadios, C. Cezeirat, C. L. Weller, and M. A. Hanna, Emulsified soy protein-lipid films. In: D. J. Sessa and J. L. Willett, Editors, Paradigm for Successful Utilization of Renewable Resources, AOCS Press, Champaign, IL (1998), pp. 213-226.

Ghorpade et al., 1995 • V. M. Ghorpade, H. Li, A. Gennadios and M. A. Hanna, Chemically modified soy protein films. Trans. ASAE 38 (1995), pp. 1805-1808.

Graveland et al., 1979 • A. Graveland, P. Bongers and P. Bosveld, Extraction and fractionation of wheat flour proteins. J. Sci. Food Agric. 30 (1979), pp. 71-84.

Kiosseoglou et al., 1999 - A. Kiosseoglou, G. Doxastakis, S. Alevisopoulos, and S. Kasapis, Physical characterization of thermally induced networks of lupin protein isolates prepared by isoelectric precipitation and dialysis. Int. J. Food Sci. Technol. 34 (1999), pp. 253-263.

Kitabatake and Doi, 1993 - N. Kitabatake and E. Doi, Improvement of protein gel by physical and enzymatic treatment. Food Rev. Int. 9 (1993), pp. 445-471.

Krochta and De Mulder-Johnston, 1997 - J. M. Krochta and C. De Mulder-Johnston, Edible and biodegradable polymer films: challenges and opportunities. Food Technol. 512 (1997), pp. 61-74.

Krull and Wall, 1969 • L. H. Krull and J. S. Wall, Relationship of amino acid composition and wheat protein properties. Baker's Digest 43:4 (1969), 30$34,36,38-39$.
McClements et al., 1993 - D. J. McClements, F. J. Monahan, and J. E. Kinsella, Effect of emulsion droplets on the rheology of whey protein isolate gels. J. Texture Studies 24 (1993), pp. 411-422.

McHugh et al., 1994. • T. H. McHugh, J. F. Aujard, and J. M. Krochta, Plasticized whey protein edible films: Water vapor permeability properties. J. Food Sci. 59 (1994), 416-419, 423.

Motoki et al., 1987 - M. Motoki, N. Nio, and K. Takinami, Functional properties of heterologous polymer prepared by transglutaminase between milk casein and soybean globulin. Agric. Biol. Chem. 51 (1987), pp. 237-239.

Naga et al., 1996 - M. Naga, S. Kirihara, Y. Tokugawa, F. Tsuda, and M. Hirotsuka, Process for producing edible proteinaceous film. US Patent no. 5,569,482, 1996.

Ogale et al., 2000 - A. A. Ogale, P. Cunningham, P. L. Dawson, and J. C. Acton, Viscoelastic, thermal, and microstructural characterization of soy protein isolate films. J. Food Sci. 65 (2000), pp. 672-679.

Okamoto, 1978 - S. Okamoto, Factors affecting protein film formation. Cereal Foods World 23 (1978), pp. 256-262.

Rampon et al., 1999 • V. Rampon, P. Robert, N. Nicolas, and E. Dufour, Protein structure and network orientation in edible films prepared by spinning process. J. Food Sci. 64 (1999), pp. 313-316.

Rangavajhyala et al., 1997 - N. Rangavajhyala, V. M. Ghorpade, and M. A. Hanna, Solubility and molecular properties of heat-cured soy protein films. J. Agric. Food Chem. 45 (1997), pp. 4204-4208.

Rhim et al., 1998 - J. W. Rhim, A. Gennadios, C. L. Weller, C. Cezeirat, and M. A. Hanna, Soy protein isolate-dialdehyde starch films. Ind. Crops Prod. 8 (1998), pp. 195-203.

Rhim et al., 1999a - J. W. Rhim, A. Gennadios, D. Fu, C. L. Weller, and M. A. Hanna, Properties of ultraviolet irradiated protein films. Lebensm. Wiss. Technol. 32 (1999), pp. 129-133.

Rhim et al., 1999b • J. W. Rhim, Y. Wu, C. L. Weller, and M. Schnepf, Physical characteristics of a composite film of soy protein isolate and propyleneglycol alginate. J. Food Sci. 64 (1999), pp. 149-152.

Rhim et al., 2000 - J. W. Rhim, A. Gennadios, A. Handa, C. L. Weller, and M. A. Hanna, Solubility, tensile, and color properties of modified soy protein films. J. Agric. Food Chem. 48 (2000), pp. 4937-4941.

SAS, 1993 - SAS, 1993. SAS/STAT User's Guide. Release 6. 08. SAS Institute, Cary, NC.

Stuchell and Krochta, 1994 - Y. M. Stuchell and J. M. Krochta, Enzymatic treatments and thermal effects on edible soy protein films. J. Food Sci. 59 (1994), pp. 1332-1337.

Were et al., 1999 - L. Were, N. S. Hettiarachchy, and M. Coleman, Properties of cysteine-added soy protein-wheat gluten films. J. Food Sci. 64 (1999), pp. 514-518.

Yildirim and Hettiarachchy, 1997 - M. Yildirim and N. S. Hettiarachchy, Biopolymers produced by cross-linking soybean 11S globulin with whey proteins using transglutaminase. J. Food Sci. 62 (1997), pp. 270-275. 